\title{
Resistance to Intelligently Controlled Low Air Humidity and High Temperature of Cymbidium Luck Gloria
}

\author{
Chuangui Yang ${ }^{\mathrm{a}}$, Yubao Gao ${ }^{\mathrm{b}}$, Ling $\mathrm{Xu}^{\mathrm{c}}$ \\ ${ }^{a, b}$ College of Life Science, Nankai University, Tianjin 300071, China \\ ${ }^{c}$ Tianjin Institute of Urban Construction, Tianjin 300384, China
}

\begin{abstract}
The paper conducted thorough research on the adaptability of Cymbidium Lucky Gloria (CLG) through different temperature and relative humidity levels by using intelligent artificial climate chamber. The effects of single and tow collaborated factors on plant surviving are explored. It finds that temperature's role in CLG surviving is the most significant. The surviving rate reaches only $23.0 \%$ with the extreme level of temperature $\left(41^{\circ} \mathrm{C}\right.$, first period; $24^{\circ} \mathrm{C}$, second period). Extreme high temperature surpasses the endurance of heat shock proteins (HSPs), and leads the plants died. The survived plants under extreme levels are of excellent attributes for the succeeding strain invention.
\end{abstract}

Index Terms: temperature, relative humidity, Cymbidium Lucky Gloria (CLG), extreme

(C) 2012 Published by MECS Publisher. Selection and/or peer review under responsibility of the Research Association of Modern Education and Computer Science.

\section{Introduction}

Nowadays, Many hybrid cymbidium varieties are introduced into Tianjin and China[8,9], and some of them gradually faded away because of low tolerance to Tianjin' environment. Cymbidium Lucky Gloria (CLG) is hybridized by Cymbidium Lucky Rainbow (mother parent) and Cymbidium Red Gloria (father parent). It was registered on the Sander's List in 1996. The aboriginals include Cymbidium Insigne Rolfe, Cymbidium Lowianum Rchb. F., Cymbidium Erythrostylum Rolfe, Cymbidium Eburneum Lindl, Cymbidium Tracyanum L. Castle, Cymbidium Iansonii, Cymbidium Hookerianum Rchb F., Cymbidium Pumilum, Cymbidium Parishii (Rchb. F.), and Cymbidium Schroederi. These aboriginals crossbred generation by generation, and finally the current variety is acquired. It is a medium temperature and humidity tolerance variety[16].The variety was imported into Tianjin several years ago. The normal growth circumstance in Tianjin and northern China are different from its original one [13,14]. It is unknown that its adaptability to indoor environment and normal

* Corresponding author.

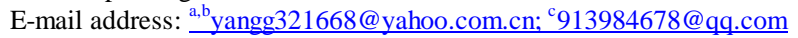


greenhouse environment, especially for high temperature and low relative humidity, under the Tianjin and northern China's weather conditions. The goal of this research is trying to answer the urgent questions through experiments in controlled and intelligent climate chamber. Furthermore, it will lay a foundation to the succeeding research on new strain invention through extreme value test of temperature and relative humidity.

\section{Materials and Methods}

\subsection{Plantlets used for experiment}

Mature and flowering pot plants of CLG were cultivated in the greenhouse, and to supply buds. Buds grown from the protocorm were cut down [15], and disinfected with a $2 \%$ sodium hypochlorite solution under the vertical laminar flow cabinet. Then, they were transferred into prepared containers containing medium. Medium composition: Murashige and Skoog (MS) + 6-BA $3.0 \mathrm{ml} \mathrm{l}^{-1}+\mathrm{IBA} 0.2 \mathrm{ml} \mathrm{l}^{-1}+$ charcoal $3.0 \mathrm{~g} \mathrm{~L}^{-1}[12$, 2]. The buds differentiated and grew in the culturing room for about 9 months. Afterwards, the plantlets were transferred into greenhouses for acclimatization.

\section{Resistance test}

Transferred plantlets are acclimatized for 6 months in greenhouse, then put them into intelligent artificial climate chamber (LRH-350) in several batches. 30 plants per batch. The substrate is composed of moss and pine tree bark. The ratio is: moss : bark $=3: 1$.

The treatments for temperature, relative humidity, and light intensity control are as follows:

Treatment time is divided into two periods: first period is from 11:00 to 18:00. The second stage is 18:01 to 10:59. Light intensity is $14 \mu \mathrm{E} /\left(\mathrm{m}^{2} \mathrm{~s}\right)$ [10,1]for the first period, and for the second one is 0.0 .

Temperature treatments are listed in table1. Relative humidity is fixed to 55.0\%. Humidity treatments [13] are shown in table 2. Temperature is fixed to $24.0^{\circ} \mathrm{C}$ for the two periods. Three treatments are involved for temperature and relative humidity, respectively. 30 plants per treatment, and the treatments last for 45 days.

Collaborated experiments. Temperature and relative humidity are considered at the same time. Levels and factors appear in table 3.

Statistics are conducted when the experiment is completed. Morphological methods are used to make quick appraise to the results and to give instructions to the following experiment and reproduction. Physiological and biochemical activity are not suitable for the appraisement. The following is the classification standards:

Died plants (DP): protocorm has shrunk, stems and leaves dried rot.

Injured plants (IP): stems and leaves dried rot, but the protocorm has not shown evident shrinking.

Healthy plants (HP): stems, leaves, protocorm do not show evident shrinking, and can maintain normal growth.

Finally, the surviving rate is calculated based on the above classification standard and the following equation:

$$
\mathrm{SR}=\mathrm{HP} / \mathrm{TP}
$$

Where

$\mathrm{SR}=$ Surviving rate;

$\mathrm{HP}=$ the number of healthy plants;

$\mathrm{TP}=$ total plants. 


\section{Results and discussion}

\subsection{One factor results}

Experiment results of temperature and relative humidity are shown in table 4, table 5, and Fig. 1, respectively. Level 1 is the extreme temperature, and gets the lowest surviving rate (23.0\%). Greenhouses under natural conditions, i.e. without cooling and heating measures are taken, often reach this high temperature, especially in summer time. If the hybrid cymbidium can survive at this temperature, they have great resistance ability to high temperature stress, which is what we want, and can be reproduced in mass. Level 2 and level 3 are just for test controlling although they have higher surviving rate. It needs much effort to reach this temperature level in natural greenhouses and housing rooms.

The effects of relative humidity is less significant compared with that of temperature. The surviving rate got $63 \%$ even the relative humidity at day time reach the extreme value.

Table 1. Temperature Treatment

\begin{tabular}{lcc}
\hline Levels & First period $\left({ }^{0} \mathrm{C}\right)$ & Second period $\left({ }^{0} \mathrm{C}\right)$ \\
\hline Level 1 & 41 & 24 \\
Level 2 & 35 & 21 \\
Level 3 & 32 & 18 \\
\hline
\end{tabular}

Table 2. Relative Humidity Treatment

\begin{tabular}{lcc}
\hline Levels & First period & Ssecond period \\
\hline Level 1 $(\%)$ & 10.0 & 50.0 \\
Level 2 $(\%)$ & 20.0 & 65.0 \\
Level 3 $(\%)$ & 60.0 & 75.0 \\
\hline
\end{tabular}

Table 3. Collaborated Experiments

\begin{tabular}{llll}
\hline Levels & & First period & Second period \\
\hline Level 1 & Temperature $\left({ }^{0} \mathrm{C}\right)$ & 41 & 24 \\
& Humidity $(\%)$ & 10.0 & 50.0 \\
Level 2 & Temperature $\left({ }^{0} \mathrm{C}\right)$ & 35 & 21 \\
& Humidity $(\%)$ & 20.0 & 65.0 \\
Level 3 & Temperature $\left({ }^{0} \mathrm{C}\right)$ & 32 & 18 \\
& Humidity $(\%)$ & 60.0 & 75.0 \\
\hline
\end{tabular}

Table 4. Temperature Results

\begin{tabular}{ccccc}
\hline Levels & Total number & Died & Survived & $\begin{array}{c}\text { Surviving percentage } \\
(\%)\end{array}$ \\
\hline Level 1 & 30 & 23 & 7 & 23.0 \\
Level 2 & 30 & 6 & 24 & 80.0 \\
Level 3 & 30 & 0 & 30 & 100.0 \\
\hline
\end{tabular}


Table 5. Results of Relative Humidity

\begin{tabular}{ccccc}
\hline Levels & Total number & Died & Survived & $\begin{array}{c}\text { Surviving percentage } \\
(\%)\end{array}$ \\
\hline Level 1 & 30 & 11 & 19 & 63.0 \\
Level 2 & 30 & 4 & 26 & 87.0 \\
Level 3 & 30 & 2 & 30 & 93.0 \\
\hline
\end{tabular}

\subsection{Collaborated factor experiment}

From table 6, we can see that the surviving rate at the extreme treatment, i.e. temperature $41{ }^{\circ} \mathrm{C}$ and $24^{0} \mathrm{C}$, relative humidity $10 \%$ and $50 \%$, attains $37.0 \%$. It is lower than that of treatment with single relative humidity, which is as high as $63.0 \%$. Therefore, the role of high temperature is more significant than humidity in relation to plant death. According to Liu Q.L. [2] bud germination is closely relevant to day temperature. Tests with four varieties of Cymbidium hybridum, including 'Xing-yu', 'Ying-xiong', 'Zhi-nv', Xiang-jiao-chuan'and 'Niulang', show that the temperature rose $26-27{ }^{\circ} \mathrm{C}$ from $23-25{ }^{\circ} \mathrm{C}$, the diameter of sprout of'Xing-yu' and'Zhinv'significantly increased, and the increment of the sprouts of all varieties significantly increased with the temperature increasing. Temperature's function is evident. We think that heat shock proteins (HSPs) exist in CLG $[5,7]$. But it is highly temporal and conserved. Its function is lost when high temperature treatment lasts 45 days, and bring about the plant death. For the plants survived, HSPs is of higher endurance and adjustment ability during the shift between day and night, and finally achieve survivorship.

Table 5. Results of Collaborated Factors

\begin{tabular}{ccccc}
\hline Levels & Total number & Died & Survived & $\begin{array}{c}\text { Surviving percentage } \\
(\%)\end{array}$ \\
\hline Level 1 & 30 & 19 & 11 & 37.0 \\
Level 2 & 30 & 7 & 23 & 77.0 \\
Level 3 & 30 & 3 & 27 & 90.0 \\
\hline
\end{tabular}

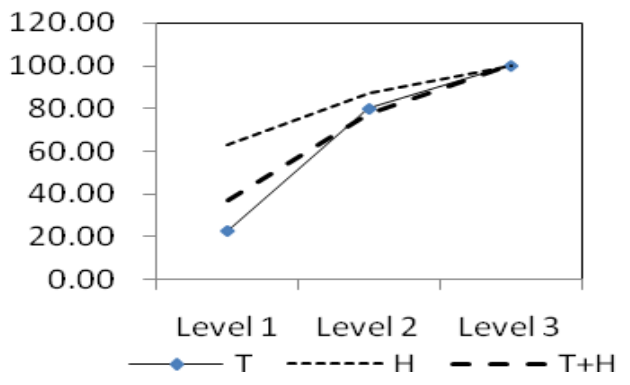

Fig. 1. The relationship between treatment levels and surviving rate. 


\subsection{Explanation to level 3}

It is worthy of explaining level 3 for both temperature, relative humidity, and the collaborated treatment, independently. We can see that the surviving rate for the three treatments is higher than $90.0 \%$. Here it should be noticed that those died plants is caused by diseases instead of temperature or relative humidity. It also should be indicated that the temperature and humidity set in the experiment level 3 can not be kept at the normal greenhouses and housing rooms [11,3] in Tianjin area and northern china, although the surviving rate is higher. For intelligent controlled artificial greenhouses, the conditions can be achieved. But a great amount of energy has to be consumed in order to maintain the pre-set temperature and relative humidity. Whereas, it is not practical, and not our purpose.

\section{Conclusions}

With the thorough research, it is evident that CLG is of high resistance to extreme temperature and relative humidity, which is key characteristics for it to be cultivated in normal greenhouses and housing rooms in Tianjin area and northern China. For the plants to be survived, the role of temperature is more significant that of relative humidity. The survived plants will be of good attributes to the succeeding new strain invention under further experiments.

\section{References}

[1] S. Caillot, E. Rosiau, C. Laplace, B. Thomasset, "Influence of light intensity and selection scheme on regeneration time of transgenic flax plants", Plant Cell Rep.No. 28, pp.359-371, 2009.

[2] C. Chang, W.C. Chang, "Micropropagation of cymbidium ensifolium var. misericors through callus-derived rhizomes", In Vitro Cell. Dev. Biol. Plant, No. 36:517-520, November-December, 2000.

[3] F. Feng, L. C. Qiu, W. Liu, "Application of Fuzzy Control in Greenhouse Temperature and Humidity Control System”, Journal of Agricultural Mechanization Research, Vol. 31, No.6, pp. 148-150, 2009.

[4] A. González, L. Ayerbe, "Effect of terminal water stress on leaf epicuticular wax load, residual transpiration and grain yield in barley", Euphytica, DOI 10.1007/s10681-009-0027-0, August, 2009.

[5] X. F. Huang, S. Z. Huang, J. R. Fu, "Regulation of Expression and Functions of the Heat Shock Proteins of Plant”, Chinese Bulletin of Botany, Vol.16, No.5, pp. 530-536, October, 1999.

[6] International Registration Authority for Orchid Hybrids, "New Orchid Hybrids", The Orchid Review, Vol. 105, No. 1213, pp. 52-54, 1996.

[7] H. F. Li, H. X. Feng, S. J. Guo, "Characteristics and applica tion of plant heat shock protein promoter", Journal of Anhui Agri. Sci., Vol. 36, No. 29, pp. 12605 - 12606, 2008.

[8] Q. L. Liu, Y. F. Jiao, G. L. Wu, "Effects of temperature on sprouting and growth of the new bud of 5 cultivars of Cymbidium hybridum", Southwest China Journal of Agricultural Sciences, Vol.121, No.16, pp. 1702-1705, December, 2008.

[9] J. B. Qin, D. Q. Lin, "Effects of different treat time at high elevation on the flower bud differentiation of Cymbidium", Guangdong Agricultural Sciences, No.8, pp. 91-92, August, 2008 .

[10] S. F. Siebert, "From shade- to sun-grown perennial crops in Sulawesi, Indonesia: implications for biodiversity conservation and soil fertility", Biodiversity and Conservation No.11, pp. 1889-1902, 2002.

[11] J. Sun, J. Liu, Y. Li , "Analysis and Research of Monitoring and Control on Greenhouse Environment in Installation Agriculture”, Hunnan Agricultural Machinery, No.3, pp.45-46,2010. 
[12] H. Vejsadová, "Factors affecting seed germination and seedling growth of terrestrial orchids cultured in vitro", Acta Biologica Cracoviensia Series Botanica, Vol. 48, No.1, pp. 109-113, 2006.

[13] X. J. Yang, "The effects of different stromata on the growth and development of the plant Cymbidium faberi”, Northern Horticulture, No.4, pp. 101-102, April, 2009.

[14] L. P. Yang, J. Y. Zhu, Y. J. Xu, X. S. Jia, X. L. Zhang, and X. R. Wen, "Study on Growing Cymbidium Grandiflorium in a Large Scale in Common Energy-saving Sunny Green Houses in Northern China", Journal of Shanxi Agricultural Sciences, Vol.34, No.1, pp. 44-46, February, 2006.

[15] F. P. Zhang, J.S. Fan " "Study on Cutting Experiment of Hibisus rosa-sinensis", Northern Horticulture, No.12, pp. 177-178, 2007.

[16] J. Z. Zhao, C. G. Wan, J. M. Chen, G. G Tang, and S. S. Li, "Effects of Different Media Water Deficiency on Physiology of Cymbidium hybridum", Journal of Nanjing Forestry University (Natural Sciences Edition) Vol. 27, No.2, pp. 29-32, March, 2003. 